\title{
Understanding first-generation undergraduate engineering students' entry and persistence through social capital theory
}

\author{
Julie P. Martin ${ }^{1 *}\left(\mathbb{D}\right.$, Shannon K. Stefl ${ }^{2}$, Lindsey W. Cain ${ }^{3}$ and Aubrie L. Pfirman ${ }^{4}$
}

\begin{abstract}
Background: The higher education literature is replete with deficit-based studies of first-generation college students. By thinking of students' social relationships as embedded assets, our research adds to an anti-deficit, or asset-based, framing of first-generation students majoring in engineering. Our multi-institution study qualitatively characterizes how the various people (alters) in students' social networks provide expressive and instrumental social capital that helps students decide to enter and then to persist in undergraduate engineering majors. Our work compares and contrasts social capital assets described by first-generation college students and those described by continuing-generation college students.

Results: Both first-generation college students and continuing-generation college students described how they leveraged the social capital inherent in their social relationships. In our comparison of the two groups, we found far more similarities than differences in the way participants described their social capital. For example, the network compositions (the specific alters providing resources) were similar for both groups. Both groups reported how parents, family members, peers, middle and high school teachers, individuals associated with science, technology, engineering, and mathematics programs, university professors, academic advisors and other personnel, employers and coworkers, professional organization contacts, and graduate students provided social capital related to major choice and persistence. One difference between the two groups relates to the type of social capital provided by parents and intergenerational family members. First-generation college students described their familial relationships as assets that provided robust emotional support (expressive social capital) while the students decided upon a college major and vigorous encouragement to persist once the students enrolled in undergraduate studies. Continuinggeneration college students described their families as providing engineering-specific instrumental actions and information during their selection of a college major, and then familial support changing to that of an expressive nature while the students were enrolled in engineering studies.

(Continued on next page)
\end{abstract}

\footnotetext{
* Correspondence: martin.4071@osu.edu

${ }^{1}$ Department of Engineering Education, The Ohio State University, 244

Hitchcock Hall, 2020 Neil Avenue, Columbus, OH 43210, USA

Full list of author information is available at the end of the article
}

\section{Springer Open}

(c) The Author(s). 2020 Open Access This article is licensed under a Creative Commons Attribution 4.0 International License, which permits use, sharing, adaptation, distribution and reproduction in any medium or format, as long as you give appropriate credit to the original author(s) and the source, provide a link to the Creative Commons licence, and indicate if changes were made. The images or other third party material in this article are included in the article's Creative Commons licence, unless indicated otherwise in a credit line to the material. If material is not included in the article's Creative Commons licence and your intended use is not permitted by statutory regulation or exceeds the permitted use, you will need to obtain permission directly from the copyright holder. To view a copy of this licence, visit http://creativecommons.org/licenses/by/4.0/. 


\begin{abstract}
(Continued from previous page)
Conclusions: Our findings illustrate that engineering undergraduates' social relationships and networks are critical to their success in engineering. The relational assets first-generation college students possess support an anti-deficit framing of this group. Our work helps us understand specifically how students gain support from a variety of alters, and it provides implications for how to better support all students' engineering educational pathways.
\end{abstract}

Keywords: Asset-based, Anti-deficit, First-generation college, Multi-institution study, Choice, Persistence, Qualitative, Social capital, Expressive, Instrumental

\section{Introduction}

The educational system in the United States has historically been set up in ways that provide differential advantages to students who have college-educated parents and differential disadvantages to students whose parents are not college-educated, and these two groups are often compared in the educational literature (e.g., Lohfink \& Paulsen, 2005; Pascarella, Pierson, Wolniak, \& Terenzini, 2004; Portes, 1998). When first-generation college (FGC) students-defined in this study as students for whom neither parent who has earned a four-year college degree-are studied, researchers often explicitly or implicitly adopt a deficit mentality. Deficit thinking is personcentered and characterizes FGC students as needing to be "fixed" rather than focusing on ways to make the educational system more inclusive (Valencia, 1997). Many studies of FGC students have a "myopic focus" (Garrison \& Gardner, 2012, p. 7) on what the students lack (e.g., academic preparation, financial resources), rather than focusing on what assets students bring to their education. Further, educational researchers tend to focus on barriers encountered by FGC students, rather than on what contributes to their success (Garrison \& Gardner, 2012; Moschetti \& Hudley, 2015).

A growing number of researchers have called for the use of anti-deficit, or asset-based, frameworks for studying students in science, technology, engineering, and math (STEM), especially those from underrepresented or marginalized backgrounds (Castro, 2014; Harper, 2010; Johnson, Brown, Carlone, \& Cuevas, 2011; Martin \& Garza, 2020; Pawley, 2019; Rahm \& Moore, 2016; Syed, Azmitia, \& Cooper, 2011). While FGC students are underrepresented in STEM, they have comprised a growing population in higher education over the last two decades (Chen, 2005; Cataldi, Bennett \& Chen, 2010); this increase makes them an increasingly important part of the potential STEM talent pool. Harper (2010) laid out an argument for researchers to reframe research questions from an anti-deficit perspective and names a variety of theories that can help researchers achieve this goal. Social capital-that is, the resources gained through relationships-is one such helpful theory. Social capital is based on the idea that social relations influence an individual's goal attainment. Social capital is an asset-based framework because it treats an individual's social relationships as inherent assets. Harper explained that social capital elucidates how underrepresented students "cultivate meaningful and value-added relationships with STEM faculty and professionally well-connected others in the field" (p. 68). While Harper's work specifically focused on students of color, his framing denoted an essential shift that can be applied to all underrepresented or marginalized students. Harper suggested writing explicit anti-deficit research questions, and he proposed to explore familial factors, $\mathrm{K}-12$ school forces, out-of-school college preparatory experiences, college classroom interactions, out-of-class engagement, and experiential or external opportunities such as undergraduate research (p. 70).

Studying recruitment and retention using social capital moves the responsibility for student success away from the individual student and over to the educational system. Social capital treats an individual's social network as an intrinsic asset that can be a source of information and resources (Lin, 2001; Son \& Lin, 2012; van der Gaag \& Snijders, 2003). A social capital framing helps the STEM education community (1) acknowledge the differential advantages students whose parents are collegeeducated can accrue; (2) develop ways to leverage the strength of students' social networks; and (3) mitigate differential advantages inherent in the current system so that all students have access to abundant resources that facilitate their success. Specifically, social capital helps educators recognize and provide specific actions they can take to connect students with resources and make the process of resource access and activation less ambiguous to students (Martin, Simmons, \& Yu, 2013; Pascarella et al., 2004; Trenor, 2009).

Our analytical choice to focus on generational status in college provides an opportunity to illuminate the positive relationships that help FGC (and continuinggeneration college [CGC]) students decide to major and persist in engineering; our analytical choice rejects the perpetuation of the deficit framing of FGC students that is so prevalent in the literature. We recognize that students hold many intersectional identities. Orbe's (2004) work, for example, discussed the many identities that first-generation college students often navigate. We 
focused on generational status in college for this study because of author Martin's prior work and that of others has shown that systemic inequities exist in educational social capital based on parental educational attainment (Chen \& Carroll, 2005; Choy, 2001; Holland, 2010; Martin et al., 2013; Pascarella et al., 2004; Portes, 1998). While researchers have acknowledged that firstgeneration college students are "working from a position of disadvantage" (Holland, 2010, p. 122) because of these inequities, FGC students also report staunch support from family, school personnel, and peers for their college plans overall as well as support for their plan to major in engineering specifically (Gofen, 2009; Holland, 2010; Martin, Simmons, \& Yu, 2014; Moschetti \& Hudley, 2015). Supports like these are social capital assets. Family support appears not only as tangible actions, such as providing financial help (Holland, 2010), but also as intangible aspects like emotional support (Holland, 2010; Moschetti \& Hudley, 2015).

We are interested in learning about how the people (the alters) in engineering students' social networks help them enter and persist in their major and what type of social capital (instrumental or expressive) these alters provide. Following Harper's (2010) example of framing research questions from an anti-deficit perspective, we framed our questions around understanding what resources and supports both FGC and CGC students possess and engage in their networks as assets rather than focusing on what social capital FGC students lack.

Our research questions asked the following:

1. Whom do engineering students identify as providing resources and support important to their entry and persistence in undergraduate studies?

2. How do specific types of alter actions (instrumental and expressive) contribute to engineering students' entry and persistence in undergraduate studies?

3. How are the types of alters and actions alters provide similar or different for FGC and CGC engineering students?

\section{Theoretical framework}

Social capital has been theorized in different ways since the early 1980s (see Dika \& Singh, 2002 for a review of social capital in education). Bourdieu's work conceptualized the role social capital plays in perpetuating societal inequities (e.g., how the wealthy use resources and connections to maintain their advantageous social class). Bourdieu's conceptualization helps us understand why some researchers have pointed to occupational inherence of engineering students who have an engineer parent (Mannon \& Schreuders, 2007). Lin's conceptualization of social capital viewed an individual's social network as a pool of resources that helps the individual achieve a goal (Lin, 2001; Son \& Lin, 2012; van der Gaag, 2005). In the context of undergraduate engineering education, goal attainment equates to entering an undergraduate engineering major and persisting in the major (Martin, Miller, \& Simmons, 2014). Social capital theory posits that although individuals can achieve goals independently of their social networks (Lin, 2001), the resources available in their social network provide valuable assets that can be positively leveraged (van der Gaag, 2005). In addition to whom an individual knows, what the people in the individual's social network know is also critically important.

There are a few important terms associated with social capital in this study. The term "alter" refers to a person in an individual's social network who can potentially provide that individual with resources (Lin, 2001). Our work examines the alters described by engineering students as being important to their decision to major in and to persist in engineering. The other key terms are "expressive social capital" and "instrumental social capital." Expressive social capital is related to "physical health, mental health and life satisfaction" (Lin, 2001, p. 244). Expressive actions such as encouragement to stick with a major are theorized to be provided primarily by alters with whom a student has close ties, such as family members. An "ongoing and ever-present atmosphere of support" (Holland, 2010, p. 117) is another way to understand expressive social capital. Often, it is the alters with whom an individual has close ties, such as family members or friends, who provide expressive actions. Instrumental social capital helps individuals gain additional or new resources that specifically help them achieve a goal (Lin, 2001; Son \& Lin, 2012). Instrumental actions are theorized to be provided by alters with whom one has "weak ties," meaning a relationship that is not characterized by frequent or deep contact (Granovetter, 1973). In our context, instrumental actions may look like a professional contact connecting a student to an internship opportunity or it may look like a professor explaining course content during office hours.

\section{Methods}

We approach our work from a constructivist epistemology which allows us to examine the ways in which individuals construct their own knowledge about the world within their social context (Creswell, 2013). Individuals create meaning as they interact with the world around them. That is, they construct their understandings of and their meanings of reality through their experiences (Chism, Douglas, \& Hilson Jr., 2008). This constructivist epistemology is important because we seek to understand how our participants came to make meaning in the world around them (Crotty, 1998). We seek to gain insight into what connections are meaningful to 
undergraduate engineering student participants and how they understand those connections to support their decisions and success within their engineering programs.

We conducted semi-structured interviews and analyzed the data using both a priori and emergent coding approaches. Author Martin led a previous stage of this study (Martin, Miller, \& Simmons, 2014), implementing a Name and Resource Generator survey for the purposes of identifying and characterizing students' network composition, strength of ties, and resource access. The interested reader is directed to her prior work (Martin, Miller, \& Simmons, 2014) for detailed findings from the Name and Resource Generator in which she operationalized social network composition and strength of ties by asking participants to list the names of people who were influential to their academic and career decisions, as well as their relationships to those people (Dika, 2003; Lin, 1999; Lin \& Dumin, 1986; McCallister \& Fischer, 1978). In the prior work survey, she asked this question twice, once for each of two timeframes: "during the time when you were deciding to major in engineering," and "as of today," during their undergraduate studies. We used the prior work's Name and Resource Generator responses for two purposes in this paper: (1) we selected interview participants from the survey sample; and (2) we used the names of people reported in the survey to form the individualized interview guides for each participant in this study. We obtained IRB approval for both the prior work and the current work described herein.

\section{Quality considerations}

Many scholars have addressed validity and trustworthiness considerations in qualitative research (Borrego, Douglas, \& Amelink, 2009; Corbin \& Strauss, 2008; Creswell, 2013; Leech \& Onwuegbuzie, 2007; Moll, Amanti, Neff, \& Gonzalez, 1992; Morse, Barrett, Mayan, Olson, \& Spiers, 2002). Keeping this in mind, we chose to utilize Walther, Sochacka, and Kellam's (2013) "quality in qualitative interpretive research" $\left(Q^{3}\right)$ management typology. These authors described aspects of theoretical, procedural, communicative, and pragmatic validation, as well as process reliability, in two distinct stages that they termed "making the data" and "handling the data" (Walther et al., 2013; Walther, Pawley, \& Sochacka, 2015). In the remainder sections "Handling the data" and "Limitations of the sample", we have parenthetically indicated each of these measures of quality in our work. Leveraging this framework's considerations for both "making data" and "handling data," we were attuned to quality throughout the entire research process. Our adherence to the Q3 framework served as a recognized measure of quality in the field of engineering education. We consider providing a detailed example of this typology to be an additional contribution to our work.

\section{Participants}

We use the term "first-generation college" or "FGC" student to refer to a student who does not have a parent with a 4-year degree, following the U.S. Department of Education's terminology (Chen \& Carroll, 2005; Choy, 2001). Martin, Simmons, and Yu's (2014) study of undergraduates' descriptions of family roles relating to their academic and career choices supported this operationalization, showing the association between certain family roles and parental educational attainment. They found no difference between engineering students whose parents had some college experience without earning a 4-year degree (e.g., an associate's degree or some completed coursework) and engineering students whose parents possessed no more than a high school diploma. We use the term "continuing-generation college," or "CGC," to refer to a student who had at least one parent with a 4-year degree.

Participants in this study were undergraduate engineering students at one of five public institutions in the United States. Forty-seven students participated in interviews that were held in person at each participating university. In order to capture a broad range of student experiences, we utilized a strata-based purposeful maximum variation sampling based on the participants' institution, generational status in college, year in school, race/ethnicity, and gender. We improved our ability to see the full extent of the social reality under investigation (theoretical validation) by using informational considerations in our purposeful sampling (rather than random or representative samples). Students were at various stages of persistence in their undergraduate studies, ranging from students who were in their first year to students who were close to graduation. Fourteen of the 47 participants were in their first year at their institution, nine were in their second year, 11 were in their third year, nine were in their fourth year, three were in their fifth year, and one was in their seventh year. Of the 47 interview participants, 11 met the definition of FGC, and 36 had at least one parent with a 4-year college degree. Of the 36 CGC students, 15 participants reported having at least one parent who was an engineer. Table 1 shows the number of participants of each generational status by the institution. While each participant held multiple intersectional identities, this paper focuses on generational status in college because the literature has revealed this to be an important consideration in studying education-related social capital. Here, we present the experiences of both groups.

The five institutions were chosen based on characteristics of the university and engineering college within the larger institution, Carnegie 2000 classifications (specifically residential/nonresidential status, selectivity, doctoral/master's institutions), and geographic location. 
Table 1 Participant generational status in college by the institution

\begin{tabular}{lll}
\hline Institution & Number of participants & Generational status in college \\
\hline A & 9 & 2 FGC \\
& & 7 CGC \\
B & 9 & 2 FGC \\
& 7 CGC \\
C & 12 & 3 FGC \\
& & 9 CGC \\
D & 8 & 3 FGC \\
& & 5 CGC \\
E & 9 & 1 FGC \\
& & 8 CGC \\
Total & 47 & 11 FGC, 36 CGC \\
\hline
\end{tabular}

Practical considerations such as resource constraints for the federal funding source for the project were also considered. The five institutions represented four doctoralgranting universities and one masters-level institution, ranging from "inclusive" (one) and "selective" (one), to "more selective" (three) Carnegie ratings. Three of the universities are classified as predominantly White institutions, and two are Hispanic-serving institutions. One of the Hispanic-serving institutions is consistently characterized as "ethnically diverse" in U.S. News and World Report. Three institutions are "nonresidential" and two are "residential" as defined by Carnegie Classifications. Two institutions are located in the eastern United States, one in the western United States, and two in the southwestern United States.

\section{Making the data}

In order to understand how students used their social connections in making decisions to enter an engineering major in college and also how they used these social connections to persist as undergraduates, we conducted interviews with current undergraduates that focused on two separate timeframes. The first timeframe focused on student recruitment. We asked participants to think back to the period during which they were deciding to pursue engineering as a college major. We also interviewed them about their ongoing decisions to persist or not persist in their undergraduate studies. We avoided social capital jargon in our interview protocol so that participants could construct their own meanings about the influence(s) of alters on their decisions to enter and to persist in engineering. We began with an open-ended question: "Tell me about how you became interested in engineering." This prompt put participants in a frame of mind to make meaning of their decision to enter engineering. We then asked a series of semi-structured interview questions focusing on critical incidents related to the participants' decisions to major and persist in engineering, using follow-up prompts as needed. Questions included "Did you have a particular experience or hear a piece of information that made you feel that engineering was for you? (tell me about that)"; "Tell me about your experiences as an engineering student at [Name of University]; what has majoring in engineering been like for you?"; "What moments stand out as being positive or influencing you to persist?"; and "Which people or resources have been positive influences on your persistence?" We followed with prompts derived from each participant's list of names in the prior survey. We asked participants to tell us about each person they listed in the survey and to describe that person's influence on their decision to major in engineering and to persist in their undergraduate studies. These questions took the form of "Before/during your decision to major in engineering, you listed [Name of Alter] among your network. Tell me about how they helped you in your academic and career plans." Follow-up questions were asked as needed and took the form of "Can you elaborate on that?" or "Is there a particular time or event that stands out to you?" After discussing the entire list of alters, we ended with a question similar to "Is there anyone we did not discuss that you can think of who has influenced you in selecting or persisting in engineering?" By conducting the interviews in this way, we improved the fit between the theory and the reality we investigated, and we contributed to procedural, theoretical, and communicative validation in that we were using the participants' direct responses to create the individual interview guides. Our study compares and contrasts the alters that FGC and CGC engineering students indicated were important to their pursuit of an undergraduate engineering degree, as well as the types of social capital or actions each of these alters provided.

\section{Handling the data}

A professional transcriptionist transcribed the audio recordings of the interviews verbatim. The data corpus consists of a total of 759 pages of transcripts (186 pages from FGC, 573 pages from CGC). Research team members cleaned the interview transcripts by making corrections to the transcription while listening to the voice recordings (procedural validation and communicative validation). We took additional steps to address procedural validation by reviewing the transcripts for comprehension. A research team member also performed the initial coding and analysis of the FGC subset of the interviews, and the other authors served as frequent peer debriefers throughout the process. From there, two members of the research team independently memoed about the interviews with a focus on the alters and the resources they provided. 
We used a combination of deductive and inductive thematic coding. As Table 2 shows, we used the alter types taken from our prior Name and Resource Generator work (Martin, Miller, \& Simmons, 2014) as a priori codes. Several additional codes emerged from the rich interview data for alters, including siblings, individuals involved with STEM programs, professional organization contacts, and graduate students. These are shown in Table 2. We developed codes for a deeper analysis that were theoretical (i.e., those codes directly tied to social capital), structure-driven (based on our research questions), and data-driven (emergent from participant responses; Ryan \& Bernard, 2003). For example, we examined similarities and differences by generational status in college by coding for the influence of various alters at both timeframes and each type of action (expressive versus instrumental).

We took the following steps to additionally ensure the quality of our data analysis: We refined our total list of themes through several rounds of structured and unstructured memoing, coding, and debriefing, and we used direct quotes from the interviews in the memoing stages as low-inference descriptors to stay true to the participants' meanings (communicative validation). We revisited the themes and compared several research team members' independent codes to ensure that we were fully capturing the participants' engineering-related social capital (pragmatic and theoretical validation). We wrote memos comparing and contrasting the resources provided by the alters at each timeframe to clarify the distinction between the influence of alters on participants at the two separate time intervals. Our final quality measure involved engaging other members of the research team to discuss and challenge our understandings. We met frequently to debrief throughout the analysis process to keep other members of the research team informed of our findings (process reliability). We created preliminary models and presented them to the team, made revisions based on research team feedback, and presented the models to outside researchers for feedback at regional and local poster sessions (communicative validation). In writing the findings, we were careful to use examples from different participants.

\section{Limitations of the sample}

Our findings should be viewed in light of the boundaries of our sample and methodology. Our sample included only students who had persisted in engineering. We do not make claims about students who may have considered engineering and did not enroll, about the peers of our participants who left the program before our study, or about students who did not consider engineering. While we acknowledge that there is much to be learned from students who do not choose engineering after considering it and from students who do not persist in engineering, we concur with Harper's insight that "those who endeavor to improve student success in STEM would learn much by inviting those who have been successful to offer explanatory insights into their success" (2010, p. 71). Understanding the social capital of students who fall into the unexplored populations provides rich direction for future research.

\section{Findings and discussion}

Interviews revealed that the network compositions-that is, the specific alters providing resources-were similar for FGC and CGC students. In the sections below, we describe how each alter type provided resources and information to FGC and CGC participants during each timeframe. We present the alter influences generally in the order of salience from interview data.

\section{First timeframe \\ Middle and high school teachers}

FGC participants described middle school and high school teachers as providers of both instrumental and expressive actions. FGC students described expressive actions by teachers who recognized their aptitude in math and science. They recounted instrumental actions such as specific advice about how their talent and interest in STEM subjects would translate into skills needed in engineering coursework and they remembered suggestions to consider a college major in STEM. Many FGC participants were involved in STEM-related courses in middle or high school, either within a traditional school or as part of a magnet program, such as an academy or residential school. Some FGC students spoke of having a teacher who was an engineer by training. One

Table 2 A priori and emergent codes for salient alters

\begin{tabular}{ll}
\hline A priori codes & Emergent codes \\
\hline Parent or guardian & Sibling \\
Family member & Individual involved with STEM programs \\
Peer & Professional organization contact \\
Middle or high school teacher/personnel & Graduate student \\
Community college personnel/professor & \\
University personnel & \\
University professor & \\
Employer or coworker & \\
\hline
\end{tabular}


student who attended a magnet high school described their experience in a "Principles of Engineering" course in this way:

[The teacher] had us research each field. And that's when we started to get into each different software program ... [learning about] how do we measure things, how do we test things, how do we put a research paper together. I learned APA format, I learned, of course, HTML. [My] sophomore year I was already into digital electronics because my teacher at my sophomore level, he was a retiree [from the] Navy. So, he was an electrical engineer . . . then junior year my teacher was also an engineer and she worked in a manufacturing plant.

Learning software packages, HTML programming, and digital electronics was instrumental social capital that exposed the participant to engineering-related topics. Another FGC participant spoke of their high school physics teacher in an analogous manner:

I had him for high school physics, and specifically when I started taking that class he saw that it was something that came easy to me and he says, "Yeah, I think engineering would be something good for you ... you're doing well in physics so far, I think you should keep going in that direction." And I took his advice.

The advice to pursue engineering was an instrumental action on the part of the student's physics teacher.

CGC participants also discussed middle school teachers and high school teachers who recognized their aptitude for math and science (expressive) and encouraged them to pursue an engineering degree (instrumental). CGC participants described how their high school teachers encouraged them to have a strong work ethic, which helped them succeed in college coursework (instrumental). Participants also described how teachers made engineering topics interesting, which helped them to learn to think like an engineer (instrumental). Teachers also told them what it was like to do engineering work. This was an instrumental action that helped them make an informed choice about their college major.

\section{STEM program personnel}

Some FGC participants were involved in college preparatory programs such as the U.S. Department of Education's TRIO program and subsequently became involved in STEM summer camps and other pre-college programs. (TRIO is a program offered by the Department of Education that seeks out and assists low-income, first- generation college, and/or disabled students to help them succeed through middle school to higher education.) Participants described the influence of individuals associated with these informal educational activities as providing instrumental help such as the resources they needed to choose engineering. For example, one FGC participant talked about how their TRIO mentor used his connections at a large aerospace company to set up two, day-long tours:

[My TRIO mentor] left me with the engineers. That's the thing, we were supposed to stay there [without the mentor so that the student would be the one to] ask the questions without, someone to be like, "Hey guys, ask a question!" like the usual field trips. . . . That was amazing. . . . And they took me to all the departments. [And I asked] everything like, how is it possible for me to get in there? Could I use them as contacts? . . . What type of scholarships [do they offer]?. . What were they looking for when they hired people? Because, you know, I expected and they expected that I would graduate and I would look for a job ... that's what it was all about, to actually get a feel of the companies themselves.

The act of setting up these tours on behalf of the student was instrumental social capital because the participant learned about various aspects of engineering, gained valuable contacts in the field, and received answers to their questions about future employment at the company.

STEM program personnel like those who work with TRIO provided some FGC participants with their first exposure to specific engineering content knowledge (instrumental). STEM program personnel introduced engineering careers (instrumental) and they also served as role models (expressive) for participants. One student described their experience at a summer program that was recommended by a guidance counselor:

I went to a summer camp, summer after my sophomore year of high school ... what they [the organizers] do is they ask you about your interests and they try and pair you with something or a program that they think would be best suitable for your interests. So, I put math in there [on the form] and so they gave me a math class, they gave me a chemistry class and engineering class. And so, it was kind of my first like experience with engineering and . .. I had a lot of fun with it. I really liked all the things that I did there, and they taught us about computer modeling, and we learned how to use . . . I think it was AutoCAD. And then I also really, really liked my 
chemistry class and so after that I was really interested in chemistry, as well as engineering. So thus, I decided to pursue chemical engineering as an option.

The counselor's summer camp recommendation was an instrumental action, as was engineering-related content knowledge shared by the summer program instructors. These actions exposed the student to engineering topics that led to their decision to major in chemical engineering.

Another FGC participant talked about how participating in a STEM program led to a new perception that the engineers were not like their pocket-protector-wearing stereotype:

[I]n the program we were able to meet engineers so that kind of led me to get at least an understanding of their personalities as well because people say that there's a stereotype within every career and that they have specific personalities. And when you meet them, you get to see . . . how they are. . . . And they were just chill, very down-to-earth people.

In this example, getting to know engineers from the program was instrumental social capital because it helped the student better understand the culture of engineering and see themselves as someone who would fit into the engineering workforce.

Much like FGC students, the CGC students who participated in STEM camps or other programs described how STEM program personnel also provided instrumental actions that helped students gain early exposure to what it meant to be an engineer. The individuals associated with these programs provided students with handson experiences. One participant said that his experience in such a program led him to feel like he belonged: "I think I can see myself doing this [engineering].” CGC students said they gained engineering experience, interacted with engineers, and developed engineering interests and skills in STEM programs-all instrumental social capital-that had led the students to take engineering-related courses in high school, such as drafting or STEM courses. For example, one CGC student said:

[I]t wasn't until I did a summer camp . . I I was at the time vacillating between being a chemistry major or a chemical engineer. I didn't know what a chemical engineer did. And through the course of that week I really learned that I did want to do engineering. It would be more of an application of the science. It would allow me to do things that I actually wanted to do later on in my life as opposed to being a chemistry major stuck in a lab, being, just doing experiments all the time. I could actually apply some of it.

For this student, the summer camp was instrumental social capital because it helped them learn what they could do as an engineer and led to their decision to study engineering in college.

\section{Parents and family members}

FGC participants described expressive actions of family members who supported them "100\%." FGC participants stated that the encouragement from family to earn a college degree was steadfast regardless of major chosen. For example, one participant said of their family:

They were like, "Work hard and get a good career, that's all we want from you." ... I've talked to them about it and they're like 100\%, they're like, "Okay, you can do whatever you want and we're proud of you."

These expressive actions in the form of verbal support for getting a college degree helped the student persist in their pursuit of an engineering degree.

The families of FGC students also characterized engineering as a means to a stable career and financially secure life. In addition to broadly supporting their child to attend college, parents specifically believed a degree in engineering was a way to build a life characterized by fewer financial struggles than they had experienced. Some parents suggested or encouraged their children to pursue engineering (expressive) because the parents knew engineers and viewed these individuals as "doing well for themselves." One FGC participant described their parents' expectations that they go to college and become financially secure in this way:

I have two older siblings ... my sister went to college. My brother just graduated. I guess it's a done deal for us. It was always like they [the participant's parents] knew that college would take us a step further . . . they always believed that we should always become better than what they were so that's part of it.

For this student, parental expectations and verbal encouragement were expressive social capital that kept them motivated to persist. Other family members, such as grandparents, cousins, aunts, and uncles, also provided expressive actions in the form of encouragement to pursue a college degree. One FGC student said of their uncle, "He wants to see me do the best I can, and he encouraged me to pursue whatever I felt was good whether it be engineering or not." In addition to 
providing emotional support and encouragement, older siblings who preceded their FGC siblings to college served as role models and provided advice about college attendance; this was true even though none of the older siblings of FGC participants majored in engineering.

In contrast to the family support portrayed by FCG students, CGC participants recounted the influence of their parents in their decisions to enter engineering via instrumental actions. These actions included providing participants with STEM-related toys at an early age and enrolling them in camps and outreach programs. CGC participants described the early exposure to STEM activities as putting them "on a trajectory" towards an engineering degree. CGC students said their parents pointed to an aptitude in math or science and encouraged them to pursue these interests via expressive actions. One CGC student recounted the influence their father buying an electronics kit had on them:

I think one influence that got me into electronics was my father buying me an electronics project kit at Radio Shack ... so I used to play with that electronic project kit putting together some of the different circuits in it. At the time I didn't really understand what I was putting together but I just enjoyed putting things together. And eventually I got into the enjoyment of taking things apart and like looking inside.

This was a powerful instrumental action that led to the participant's eventual pursuit of electrical engineering.

Many CGC participants had a parent who was an engineer. These students described memories of immersion in the world of engineering through both instrumental actions by their engineer parent(s), such as dinner table discussions and visits to parents' places of work, as well as expressive actions in the form of encouragement to follow an engineering career. For example, one participant explained that their father wanted them to be an electrical engineer so every summer he would put "a huge programming language book" on their desk and tell them, "You're going to learn this language this summer." The student learned coding-a useful skill for engineering-through these instrumental actions.

CGC students also discussed the influence of other family members in making their decision to enter engineering. Some participants described being surrounded by multiple generations of engineers, including engineer siblings and cousins. For example, one participant described sitting around the dinner table at family gatherings while relatives discussed their careers and daily lives, saying:
There must be something in the water because my grandma-all of her children are engineers except my mom. So, you know, every Christmas and summer I've been surrounded by all these people that are all super science-y and really smart and happy ... so in thinking about engineering I already had that idea.

Being surrounded by so many engineers was expressive social capital because it made the student feel like they would fit in with other engineers and it was instrumental social capital because they learned about what their relatives did in their jobs. Likewise, other CGC participants who had family members who were engineers reported aspirational feelings towards their engineer family members and expressed a desire to have a similar financially secure lifestyle. One participant observed the lifestyle of his uncle, noting, "He was happy ... . he lived near the beach, in a nice house. I mean, he just seems like he has a good life."

\section{Employers and coworkers}

Employers and coworkers provided expressive and instrumental actions for FGC and CGC participants. They sometimes acted as FGC participants' first introduction to engineering as a career option. For example, one participant was working as a draftsperson for a company that employed many engineers and a coworker provided instrumental social capital when the coworker helped the participant realize they could apply their spatial relations skills as an engineer. CGC participants spoke similarly of the influence of employers and coworkers, also crediting these individuals with expressive and instrumental actions. CGC students' employers and coworkers pointed out skills and talents that would be good for engineering. They also explained what the career of an engineer is like. In this way, employers and coworkers provided instrumental actions that influenced CGC participants' decisions to earn an engineering degree.

\section{Peers}

FGC participants did not talk about peers as important alters prior to enrolling in an engineering degree program. However, CGC participants reported that their peers provided both expressive and instrumental actions. Their peers encouraged them to major in engineering (expressive) while also suggesting helpful internships while the participants were still in high school. They also provided assistance with the college admission process (instrumental). Some participants discussed peers who were already in college and who shared useful and encouraging advice. One CGC student talked about a friend's help with the admissions process during their senior year in high school: 
I remember when I was applying for colleges, I talked to one of my friends and he basically sat me down and just gave me a whole run through of like college admissions and . . . what he thinks admissions officers are looking for, how to write a good college essay ... what you're looking at when you look for potential engineering majors and stuff like that. And so, he was really helpful in that respect.

This instrumental advice helped the participant prepare their college applications and earn acceptance into an engineering program.

\section{Community college professors}

Community college professors influenced FGC participants by suggesting engineering as an option noting their aptitude and because the participants were excelling in their courses. These professors described their previous careers as engineers to students and took the time to explain how the course content was related to engineering. They explained what the career of an engineer is like and influenced FGC participants' decisions to earn an engineering degree. One FGC participant shared how a community college professor was influential in this manner:

I took one class at night; it was a mechanical drafting course. It was just a 2-D AutoCAD course. And it was at night, so I was still working during the day full time and going to this class at night at the community college. And the guy who did the class actually was an influence on me because he worked during the day at [Name of Engineering Firm] and he was a mechanical engineer. . . . And anyway, I ended up doing well. I got the highest score in the class. ... So, then I got it into my head well, I mean, I can do this. Like I said, the professor, the instructor of the course was a mechanical engineer and I had a lot of conversations with him on the side about that. So, he kind of steered me in that direction [toward engineering], too.

The course instructor served as a role model for the student (expressive) and provided specific information about engineering coursework and careers (instrumental) in their conversations. These actions led to the participant's selection of an engineering major at the university they attended after community college.

\section{Second timeframe}

\section{Middle and high school teachers}

FGC participants often maintained contact with middle school and high school teachers who continued to take both expressive and instrumental action. Teachers offered encouragement (expressive) and sometimes content-knowledge resources such as help with homework (instrumental). One FGC participant shared that they kept in touch with their high school physics teacher throughout their time as an undergraduate:

Oh, [it's] a pretty good relationship ... I would go back to school every once in a while, and I would stop by his classroom, say hey and tell him how I'm doing. Because my brother went there [to the school] as well so whenever I would see him and go back and then talk to him . . . about how I'm doing in engineering and things like that because I guess he's the reason I'm here.

These expressive discussions encouraged the FGC student to persist in college.

Some CGC participants noted that middle or high school teachers provided instrumental help in the form of homework help and advice via email or phone if they encountered problems in college courses. CGC students did not depict expressive actions by their middle or high school teachers after enrolling in college.

\section{Parents and family members}

During college, FGC participants described their families as providing expressive social capital; several described their families as being "100\%" supportive. They referenced the expressive actions of both their parents and other family members such as encouragement to persist. In the words of one FGC participant,

I would call my mom and be like, "Mom, this class is so hard." And she'd be like, "You can do it. I know it's hard, but you can do it." ... And she would bring my spirits up a little bit. Yeah, so that always made me feel a little bit better.

In this way, the participant's mother provided emotional support to persist through the difficulty of courses.

A different FGC student said this about their mother:

She always told me "Don't, don't give up, keep trying, keep going" . . . whenever I start to fall back she kind of [says] "You're all right, just, just, just keep going." And you know, she, she puts things in perspective for me . . . right now it's like, "You're almost done, one more year and that's it." ... [And that] helps, really just makes me kind of okay.

This mother's expressive encouragement to keep going helped the student persist until graduation. 
Another FGC participant described their father's support:

He actually would sometimes come up here and visit me. . . . and he'd take me out to eat . . . it would kind of relax me a lot and I'd be like very happy to see him.

The expressive action of visits from their father helped reduce the stress the student felt about their classes. It was also common for FGC participants to state their desire to make their family proud:

My grandfather is so proud of me, he brags to like every single person that he meets about me and how I'm going to [Name of University], I'm going to be a chemical engineer, it's very satisfying knowing that my grandfather is really, really proud of me because in general he's not a very emotional person. And my dad was really happy that [chemical engineering] was the decision I made because I was considering [being a] teacher. . . I think a life as a chemical engineer is a little bit more. . . it's less financially demanding than a teacher.

The grandfather's frequent expressions of pride were expressive actions that reinforced the participant's decision to enter engineering.

When FGC students had an older sibling(s) who preceded them in college attendance, these siblings provided instrumental resources about access to engineering-specific academic and career opportunities such as informing the participants about scholarships, job opportunities, and student organizations, even though none of the siblings in our study were majoring in engineering. One FGC participant described talking with their sister:

When I talk to her about it, it's really funny, when I'm taking a certain class, I tell her about it and she's like, "Okay, you should try studying it this way or this way, make flash cards or like this." Actually, she has some great pointers and it helps me with the class because sometimes I struggle a lot trying to like grasp the material. So, she's been an influence in that way just helping me get through some obstacles in my courses.

The instrumental suggestion to make flashcards helped this participant succeed academically.

In the second timeframe, parents and other family members continued to be the most significant alters for CGC students; however, while these individuals had taken instrumental actions that influenced the decision to enter an engineering program, their primary role in helping students to persist in engineering was expressive. One CGC student said, "There have been times when I just felt I couldn't do it and they've all been just very supportive of me, [saying] 'Yes, you can.' [They] kept me going." These expressive actions took the form of emotional support and encouragement to persist and mirrored the family support enjoyed by FGC participants. In both groups, these expressive actions of family members sustained their persistence.

\section{Employers and coworkers}

FGC and CGC participants described how beneficial it was that employers and coworkers from their engineering internships shared experiences about their engineering career. The engineers in the workforce offered instrumental advice, recommending courses as well as possible career options. One FGC student described how they worked in a restaurant frequented by engineers and over the years, built relationships with these customers:

I worked at a little café since I was 18. . . [D]uring high school and college I would meet engineers that would go in and eat. And [one customer] would ask me what I was doing, and I told him, and he said, "Oh really, well, I'm an engineer and I work at this place and here's my card if you need an internship." [We discussed] codes, zoning, . . . these little personal experiences ... on top of the work. And he's doing some project right now and he's like, "Oh, I have so much paperwork to do." He does a lot of paperwork on top of project managing on the field. [Talking with him] makes me feel good. It makes me feel like I could be where they're at. It gives me ... it helps me set goals for myself as well. ... [A]s a matter of fact, he was the one that says, "I told myself I would be a PE, Professional Engineer, and have a family by age 30." That's what he told me and it kind of stuck with me because it sounds pretty good. It sounds realistic, you know. After you take your FE [Fundamentals of Engineering exam], you're studying as an engineer or under a Professional Engineer for four years until you take your PE and receive a license. So, he just told us the ways that he did it.

These conversations with the practicing engineer served as expressive and instrumental social capital. The discussions about the engineer's own career path were expressive in that they helped the student feel like they could be successful as an engineer. The offer to set the participant up in an internship and the ongoing discussions that provided specific knowledge about engineering topics such as compliance issues were instrumental 
actions. Another FGC participant described how interacting with engineers during their internship influenced them in a similar manner:

[B]ecause I worked hand-in-hand with the different design engineers and they would have sit-downs with me and ... they'd tell me about their university experiences and give me their career advice like well, "Here's what you want to do and you know, and don't do this and don't listen to them when they say this," and they'd kind of give me the downlow on how the companies are.

The instrumental career advice provided by the participant's coworkers helped the student make decisions about their future career.

CGC students also described instrumental actions of their coworkers at internships. One participant described how coworkers at an internship in the medical field helped them learn all about how engineering could be applied to developing treatments for cancer and introduced them to the potential of a career path in research.

\section{Peers}

For FGC students, the most salient alters were their peers. These peers took both instrumental and expressive actions. They were the first people to whom FGC students turned for academic help and encouragement. Participants described forming study and support groups early in their undergraduate pursuits, whether in classes and labs or as early as first-year orientation prior to the start of classes, all of which created a sense of comradery that was expressive social capital. These relationships helped FGC students maintain their academic success and persist through challenges. One FGC student described the positive effects of these expressive bonds on their persistence when they said, "I think those relationships are ultimately what has kept me in chemical engineering this long." Another FGC student stated:

But once you know people that are doing the exact same thing you are, struggling, juggling classes, it's just, you feel comfortable. . . . So that's what made me feel better knowing that they're like me.

For this student, the shared struggle with their peers enhanced their sense of belonging in engineering. One FGC participant spoke of their study group in the following manner:

It really showed me teamwork and, and sort of group collaboration, especially when we're solving problems that nobody knows how to solve, I really feel like we need to work together, toss ideas around and look at each other's notes and collaborate to try to figure out what's going on in a problem. And I think that's very beneficial for the future because when I'm working on real-life engineering problems the same process is going to be happening. You have to be tossing ideas around.

In this quote, the participant described the instrumental effect that working with their peers had on their understanding of what working on real-life engineering problems would be like.

More senior peers of FGC participants provided instrumental resources for successfully navigating the engineering curriculum; they offered advice on specific courses or professor selection, as well as strategies for studying successfully. One FGC student described learning from more senior students:

I get to meet seniors and for instance, the president [of an engineering student organization] he's a senior and the vice president is a junior and what I ask them a lot is about the classes. They're almost graduating, they've been through a lot, you know, all the classes and I really want to know what professors are like, what would I be expecting because it's never bad to be prepared ... I've seen those guys staying late to study and I'm like, "What are they studying?" It's scary but . . . I should be ready for it when the time comes. I really try to guess what's ahead ... what classes they're taking or what is a concept that I should keep in mind when I'm taking thermo fluids and such.

Learning about the classes and professors they would encounter later in the curriculum is an example of the instrumental social capital that FGC students gained through their peers. Peers served other instrumental functions by connecting FGC participants to student chapters of engineering professional organizations and making them aware of internship or co-operative education opportunities.

Peers of CGC participants also provided instrumental resources for successfully navigating the engineering curriculum. Like the instrumental social capital peers provided to FGC students, CGC students described how their peers suggested courses and specific professors to take; likewise, they encouraged involvement in professional organizations. One CGC student described specific advice given to them by a more senior peer: "Make sure in all your classes you sit at the front or in the middle, near the center ... [and] pay attention, there's less room for distraction." This instrumental advice helped the student focus in class. 
More senior peers also provided CGC students with expressive actions in the form of significant mentorship to students much like the FGC students described. CGC participants often met other peers through professional organizations, as well as in class. Many CGC participants attributed their persistence to their peers because they formed study groups and worked on their homework together and empathized with their common academic struggles. One CGC participant said:

[W]orking with groups is way better because we get to bounce ideas off each other. It just makes it more enjoyable. And just having like being able to work in groups with my peers and also having like the people ... more ahead of me, having their support there and ... if you ever have any questions . . . "Call me" or "We can just like have lunch one day and I can help you out." .. . It's just having that support there has been even more influential.

The words of this CGC student describe instrumental offers of help from their peers and the expressive way that their study group makes doing their engineering work more enjoyable. Another CGC participant described the expressive actions of their boyfriend:

$[\mathrm{H}] \mathrm{e}$ 's in engineering, too, and ... he's the one that's helped me stay in engineering because . . . things get very, very stressful, he's the one that pushes me to be to do better. . . . . He was the one that ... [said], "You're very capable, you can do better than that" and he was just there encouraging me to do my best.

The boyfriend's words of encouragement were expressive actions that helped the participant persist even when they were stressed about their coursework.

\section{Institutional alters: professors, academic advisors, and program directors}

FGC students relied heavily on institutional alters as important social capital alters once enrolled in undergraduate engineering studies. Professors, academic advisors, and program directors provided instrumental actions such as giving advice about classes, helping with course content, and providing bridges to their own professional contacts in industry and professional societies. University professors provided consistent instrumental actions related to engineering academics and careers; the regularity with which students interacted with professors amplified this influence. In addition to providing engineering content knowledge, professors shared stories of their own industry experience, introduced students to industry colleagues, arranged shadowing experiences with working engineers, and communicated internship opportunities. Participants described these actions as integral to their persistence in finishing their degree. One FGC student described how a professor connected them to industry contacts:

Because he knows so many people in the industry, he'll put us in contact with representatives from the companies that he knows and like he'll maybe give in a good word for us if he knows us. And so he'll say, "My friend from this company is hiring if you want, to go look for an internship or a full time job." And so, [the professor] is a person you can just go up to and talk to about things like this. He's really, really receptive.

The professor connecting the participant to job opportunities was an instrumental action that resulted in an internship for the participant. Another student described meeting a NASA official through their professor: "He knows a lot of people, he knows a lot of contacts and I've met, for instance, [Name of the NASA Official]." Connecting the participant to an influential person in their field is another instance of an instrumental action by a professor.

In addition to these instrumental actions, professors who took expressive actions-especially through sharing their own experiences-were described as inspirational by FGC participants. One student described feeling better about their own difficulties understanding the course material when they learned that the professor had also struggled with the same content as a student: "What I guess stuck out to me in his story is we both struggled with thermodynamics and so I guess it gave me a more optimistic outlook on thermo because he's a professor and he struggled with thermo, too." In this case, the professor's description of his own difficulty initially understanding thermodynamics was an expressive action that normalized the student's struggle with the challenging topic.

Professors who suggested that FGC participants become involved in professional organizations on campus connected participants with another set of alters: engineering professionals. FGC participants met engineering professionals who were members of local chapters of professional societies and FGC participants were able to make contact with engineers who had the potential to provide future employment opportunities. The organizations also provided instrumental opportunities to talk with working professionals about their professional experiences and to tour various workplaces.

Professors were also key in helping FGC students find undergraduate research opportunities and gave advice about pursuing graduate studies. Professors provided 
instrumental actions to FGC students through undergraduate research opportunities by both offering participants positions in their labs and helping students make connections with their colleagues for research opportunities. These research experiences furthered students' understanding of the practical applications of their course material. FGC students who participated in undergraduate research interacted with graduate students and learned more about graduate school as a potential path after graduation (see section "Graduate students"). One FGC student described how they obtained a research job:

Well [Name of Professor], my advisor sends out emails whenever there is any sort of internship job. She's really good about sending out emails and she sends tons and tons of emails with lots of opportunities. So, I got one from her that was about a summer REU [Research Experiences for Undergraduates] program, and it dealt with using MATLAB programming. I like programming, so I decided to try it out. When I was interviewed for it one of the professors was really, really impressed with me. I didn't get that particular job but I stood out to that professor so he had asked me for another interview for a different job and so then he kind of just talked to me about what they do and how I could use MATLAB in programming to help them in their lab.

In this example, the professor's instrumental actions of sending emails with research opportunities resulted in the FGC participant being hired for an undergraduate research position. Another FGC student described the advice a professor gave them about graduate school:

He's like "No, you don't have to stay in [this University] to do grad school, you can do it somewhere else." So, he kind of gave me the idea [to apply elsewhere] . . . I always have this one view sometimes and he kind of opens it up.

In this example, the participant described how the instrumental advice of their professor opened their eyes to graduate school opportunities at other universities.

In the classroom, FGC participants looked to their professors to explain applications of classroom knowledge in the real world, which helped them to persist. While professors provided instrumental resources to FGC students by providing real-world examples, sharing industry contacts, facilitating internships and research opportunities, and encouraging students to join professional organizations, they also connected "real-world" applications to engineering content. For instance, one FGC participant recalled the first day of the term:
My teacher said that the entire term we're going to be talking about stem cells. And that's a completely new field for me because I didn't realize how exciting stem cells are. So, when she started talking about that I'm like, "Wow, this is really cool! This definitely affirms that I want to be a biomedical engineer."

Here, the professor's instrumental action of demonstrating how stem cells were related to course content affirmed the participant's choice of major. Another FGC participant explained how important learning about "real-world problems" was to them:

I guess one of my struggles with engineering is relating it to actual real-life scenarios ... I'm working with an environmental lab and we research wastewater systems, which didn't seem interesting to me at first, but I really liked being able to use the stuff that I like and relate it to like an actual realworld problem. So, I think that's been the best experience because I'm able to use . . . differential equations .... and the modeling that I like to relate to a real-life scenario.

The quote illustrates how the undergraduate research experience was instrumental social capital that helped the student understand real-world problems.

Other institutional agents associated with academic advising, career, or tutoring centers also played a vital role by making FGC students aware of academic and career opportunities such as internships, as well as permanent jobs. University personnel provided valuable academic and professional guidance through instrumental actions. One FGC student explained how a staff member associated with advising connected them to interview opportunities:

There are times when companies come [to campus] outside of the career fair, for instance [Name of Engineering Company], they'll come separate from the career fair and they have information sessions and interviews, too, and [Name of Advisor] informs us about it. And only [Name of Advisor]. I mean we don't have brochures or flyers anywhere. [Name of Advisor] emails us and that's the only way we can get it [the information].

The advisor's instrumental action of emailing students about internship opportunities provided students with job leads they would not know about otherwise. Academic advisors provided other instrumental actions such as creating course schedules that satisfied the required 
curriculum and incorporated students' interests or future career goals.

FGC participants also spoke of academic advisors as attending to their needs for emotional support. Specifically, through expressive actions, university personnel helped to normalize FGC students' feelings of uncertainty about academic performance and about belonging on campus. Participants portrayed these individuals as being critical to their persistence. One student described the multiple expressive and instrumental ways their advisor influenced their persistence:

She told me "Hey, take this course" ... and there was [sic] grades that I didn't like and I would tell her I got a D in [the course] . . she's the one that pushed me to keep going. And there was a time where I couldn't even pay for school and she said, "Well, have you applied to this [scholarship]?" So, she would give me scholarships, recommendation letters, she would help me out. And then she was . . - a program coordinator for [the women-inengineering group] [and would say] "We have programs here and we also have committees, organizations." So, she just informs me where to go [for help], which helps me. I could ask her anything.

The advisor provided expressive actions in the form of emotional support that allowed this student to continue in engineering, and she provided instrumental actions in the form of making the participant aware of scholarships that could ease financial burdens, even providing recommendation letters for those applications. The advisor also pointed the student to groups that could help them succeed academically.

Institutional agents were similarly critical alters for CGC students. Academic advisors and other university personnel provided both expressive and instrumental actions by encouraging students to persist and by giving them advice about how to navigate the curriculum. Instrumental actions included monitoring students' academic performance and suggesting courses to take, telling them how to find tutors for particular subjects, and offering general guidance. University personnel also sent periodic emails alerting participants of research and internship opportunities, another instrumental action. Advisors provided expressive actions by encouraging participants who were concerned about their ability to persist in engineering because of the difficulty of the coursework. One CGC participant described their academic advisor as being like "a second mother." Another CGC student spoke of their advisor in this way:

And she's very good at sending out emails ... if an internship from a company [has] applications [that] are open, she'll send an email to the whole list serve about it and we can go to the site and check out the application and see if we want to fill it out. . . I've always had a bunch of questions about internships and classes. ... So, I'd always go to her and ask her. So, she's very approachable about that and so she kind of helped me with all that stuff.

The regular emails about job opportunities and the never-ending supply of answers to the students' questions about engineering academic and career decisions were instrumental actions on the part of the advisor. Her approachable demeanor and close relationship with the participant were expressive social capital that helped them feel comfortable in engineering.

\section{Graduate students}

FGC participants did not initially identify graduate students as being salient alters, but during interviews, several participants spoke at length about positive interactions with graduate students while working in research labs. FGC participants involved in undergraduate research experiences who had contact with graduate students revealed the instrumental and expressive benefits of these relationships, including gaining valuable insight into graduate school as a potential academic and career path after graduation and a realistic understanding of the demands of continuing their education. One participant explained their interactions with two graduate students in their research lab in this way:

The room that we are in is super tiny, so we've had to get to know each other very well because we're working in such closed proximity ... I've noticed it seems that they [graduate students] really like what they're doing. Which is good . . . so I've just kind of listened to their stories about going through the grad school process and it seems kind of scary ... I guess one of them is actually a Ph.D. student. She's doing her qualifying exams this semester. And that seemed very scary. So, it seemed very intense . . . sometimes I forget that they're grad students and I'm an undergrad because I'll go to them with questions but at the same time they've come to me with questions about modeling because I know a little bit more than they do about that. So, I think I could do it. It just seems a little, I don't know, scary now.

Getting to know graduate students personally and understanding their academic paths were expressive social capital that gave the participant more confidence in their ability to follow a similar path, even though it would involve challenges such as passing qualifying exams. The 
firsthand peek into engineering research as an academic and/or career option provided by the graduate students was instrumental social capital.

CGC students also spoke of their interactions with and observations of the graduate students with whom they worked in research labs. Like FGC participants, CGC students reported being able to envision themselves pursuing an advanced degree by talking to and observing graduate students, who took an interest in mentoring them. Like the FGC students, CGC students described expressive and instrumental interactions. One CGC student said, "They have told me about the whole process of the doctoral . . . program here at [University Name] and the research that they do, the classes they learn stuff from. ..." Another student described their graduate student mentor's actions of explanations of the research process. They explained:

I'm shadowing or actually working with graduate students . . . and a lot of that is they'll tell me to do something and my first question is, "Okay, why am I doing this?" And they'll sit there and actually tell me why I'm doing this. "Why am I putting foil across this part?" Well, foil is resistive to certain types of corrosion and different properties of the metal and this is the reason we're using it." "And why am I turning on this green laser inside this gigantic chamber?" "Well, we're actually characterizing the surface of the solar cell by diffraction." [They are] taking it from that conceptual blah-land to this is what we're doing, this is why we're doing it-oh, now I understand the concept!

These explanations about why the participant was being asked to carry out each step of the process were instrumental social capital that helped them understand scientific content and the research process.

\section{Professional organization contacts}

While many FGC participants said that professors sent them to professional organizations, siblings who were already in college also took instrumental action by suggesting that participants join specific professional organizations. The engineers whom FGC participants met through these experiences offered instrumental advice about the future and current coursework. The FGC participants also described learning about professionalism, safety, and hands-on, applied skills for careers in engineering, which they said helped them decide to continue to pursue the subject (instrumental). Professional organizations also connected them to individuals with information about graduate studies (instrumental).
The practicing engineers who the CGC students met through professional organizations gave them career advice and provided instrumental support in the form of contacts for future employment. The individuals that participants met through professional organizations offered insight into what it was like to be a working engineer and served as role models and inspiration for students to persist. One CGC student described what it was like to meet an executive in a well-respected engineering company:

It's helpful because you don't always get to meet someone of that rank or from that company every day, so just being able to know that you can talk to someone from that company or that research lab and just to see that at one point in time they were just like you trying to work and trying to get a degree and now they're at a bigger and better position. ... And so sometimes it's refreshing to know, like you're always working hard, but some day it'll all pay off because you'll get a job.

This explanation highlights the expressive social capital the participant gained by meeting this engineer, and how the engineer made the student feel like they could be successful in the field because the engineer was "just like" them. Another CGC participant remarked, "They [the working engineers] fill in ... the gaps ... not the information you can find like online and if you have any questions, they're there for you," which highlights the instrumental actions by the engineers that provided "insider" information about careers at their companies to the students.

\section{Alter and action types}

When participants were deciding to major in engineering (i.e., during the first timeframe), similar types of alters were salient for FGC and CGC students. Middle school and high school teachers, individuals associated with STEM programs, and parents and other family members were all important to students' decisions to enter engineering. Middle and high school teachers were significant alters for both groups, providing expressive and instrumental actions. Teachers were the most salient alters for FGC students' decisions to enter engineering, as they were the first (and primary) sources of information about engineering for FGC students. STEM program personnel provided similar and noteworthy instrumental actions for both groups. Parents were significant alters for FGC and CGC students, although their role differed markedly. FGC students said their parents provided expressive actions in the form of staunch emotional encouragement, whereas CGC students credited their parents with expressive actions, as well as 
instrumental actions that helped them learn about STEM fields. Additionally, FGC students reported that same-generation family members (i.e., siblings) provided instrumental actions related to college admissions processes and attendance. CGC students did not describe siblings as salient alters; this could be because parents or other different-generation family members (e.g., aunts, uncles, and grandparents) provided instrumental social capital and there was no need for siblings to do so. Some CGC students reported encouragement and advice from peers, whereas none of the FGC students did. The differences between FGC and CGC students at the first timeframe, particularly as they relate to types of alters who provided instrumental actions, could indicate that the FGC students possessed somewhat smaller, more dense networks. Table 3 summarizes the alters at the first timeframe along with the types of actions provided by alters for each group (expressive or instrumental) and examples of each action type.

Once enrolled in undergraduate engineering studies (i.e., during the second timeframe), both FGC and CGC students recounted accessing resources essential to their persistence via similar network alters who provided instrumental and expressive actions. All participants reported college experiences that included many resources, as well as many individuals who functioned to encourage students to activate those resources. Middle and high school teachers remained salient during college. They provided expressive and instrumental actions for FGC students and instrumental actions for CGC students. Both FGC students and CGC students reported that parents played key roles in their persistence. The role of parents and intergenerational family members (e.g., grandparents, aunts, uncles) for CGC students changed from both instrumental and expressive to expressive only, whereas the expressive role of parents for FGC students remained solely expressive. Older siblings who preceded FGC students into college remained salient by continuing to provide instrumental actions to their brothers and sisters enrolled in engineering. Employers and coworkers, when present in the lives of participants, provided similar expressive and instrumental actions for FGC and CGC participants. FGC students reported their peers as the most salient alters in their collegiate journey, and peers were the primary people on whom they relied for both expressive and instrumental actions. Likewise, CGC students recounted the importance of peers and the similar expressive and instrumental actions they provided. Institutional alters such as professors and advisors became extremely important alters for both groups as they navigated the collegiate environment. These alters provided numerous, similar expressive, and instrumental social capital that FGC and CGC students attributed to their persistence and academic success. Graduate students with whom participants had contact were similarly sources of expressive and instrumental actions for FGC and CGC students. Lastly, FGC and CGC benefited from the instrumental career advice given by contacts they met through professional organizations. While the social network compositions and benefits accrued from within were strikingly similar for FGC and CGC participants, some FGC students described a delay in accessing resources because they did not initially know about the resource(s) or did not understand the mechanisms by which to access the resources. This difference points to opportunities for educators to make the process of resource access and activation less ambiguous for all students so everyone can benefit equally from available resources on campuses. Table 4 summarizes the alters at the second timeframe along with the types of actions (expressive or instrumental) provided by alters for each group during enrollment in undergraduate engineering studies and examples of each.

\section{Limitations of the analysis}

Our retrospective methodology gives us insight into the social capital of students at the two separate timeframes;

Table 3 Summary of alter and action types for FGC and CGC students during the first timeframe, when deciding to pursue engineering as a college major

\begin{tabular}{|c|c|c|}
\hline Alter & FGC action type [examples] & CGC action type [examples] \\
\hline Middle/High School Teacher & $\begin{array}{l}\text { Instrumental [suggested majoring in STEM], } \\
\text { Expressive [recognized aptitude] }\end{array}$ & $\begin{array}{l}\text { Instrumental [encouraged strong work ethic], } \\
\text { Expressive [recognized aptitude] }\end{array}$ \\
\hline STEM Program Personnel & Instrumental [introduced subject matter] & Instrumental [provided hands-on experience] \\
\hline Parents \& Intergenerational Family Members & Expressive [verbalized $100 \%$ support] & $\begin{array}{l}\text { Instrumental [bought STEM toys], Expressive } \\
\text { [recognized aptitude] }\end{array}$ \\
\hline Siblings & Instrumental [pointed to college resources] & N/A \\
\hline Employer or Coworker & $\begin{array}{l}\text { Instrumental [introduced/described engineering } \\
\text { career options], Expressive [recognized skills] }\end{array}$ & $\begin{array}{l}\text { Instrumental [introduced/described engineering } \\
\text { career options], Expressive [recognized skills] }\end{array}$ \\
\hline Peers & N/A & $\begin{array}{l}\text { Instrumental [assisted with admissions process], } \\
\text { Expressive [encouraged majoring in engineering] }\end{array}$ \\
\hline Community College Professor & $\begin{array}{l}\text { Instrumental [suggested majoring in } \\
\text { engineering], Expressive [served as role model] }\end{array}$ & $\mathrm{N} / \mathrm{A}$ \\
\hline
\end{tabular}


Table 4 Summary of alter and action types for FGC and CGC students during the second timeframe, during engineering undergraduate studies

\begin{tabular}{|c|c|c|}
\hline Alter & Action type, FGC [example] & Action type, CGC [example] \\
\hline Middle/High School Teacher & $\begin{array}{l}\text { Expressive [encouraged to persist], Instrumental [helped } \\
\text { with homework] }\end{array}$ & Instrumental [helped with homework] \\
\hline $\begin{array}{l}\text { Parents and Intergenerational } \\
\text { Family Members }\end{array}$ & Expressive [encouraged to persist] & Expressive [encouraged to persist] \\
\hline Sibling & Instrumental [suggested study tips] & N/A \\
\hline Employer or Coworker & $\begin{array}{l}\text { Instrumental [shared content knowledge about } \\
\text { subdisciplines], Expressive [helped student feel } \\
\text { they could be successful as engineer] }\end{array}$ & $\begin{array}{l}\text { Instrumental [shared content knowledge } \\
\text { about subdisciplines] }\end{array}$ \\
\hline Peers & $\begin{array}{l}\text { Expressive [shared own struggles], Instrumental } \\
\text { [suggested coursework and professors] }\end{array}$ & $\begin{array}{l}\text { Expressive [shared own struggles], Instrumental } \\
\text { [suggested coursework and professors] }\end{array}$ \\
\hline $\begin{array}{l}\text { Professors, Academic Advisors, and } \\
\text { Program Directors }\end{array}$ & $\begin{array}{l}\text { Expressive [normalized students' feelings and } \\
\text { struggles], Instrumental [connected to job } \\
\text { opportunities] }\end{array}$ & $\begin{array}{l}\text { Expressive [encouraged to persist], Instrumental } \\
\text { [connected to job opportunities] }\end{array}$ \\
\hline Graduate Students & $\begin{array}{l}\text { Expressive [took interest in students], Instrumental } \\
\text { [gave insight about graduate pathways] }\end{array}$ & $\begin{array}{l}\text { Expressive [took interest in students], } \\
\text { Instrumental [gave insight about graduate } \\
\text { pathways] }\end{array}$ \\
\hline Professional Organization Contacts & Instrumental [gave career advice] & Instrumental [gave career advice] \\
\hline
\end{tabular}

it does not follow them longitudinally. Longitudinal study is an area that merits future research. Additionally, our analysis of engineering undergraduate participants does not distinguish between participants who were in various years in their undergraduate studies. Therefore, our conclusions do not speak to how social capital changes throughout the undergraduate experience. This area is also a stimulating nuance to explore in further work.

\section{Conclusions and future research directions}

Our work offers specific examples of how entry and persistence in engineering majors are linked to the relationships students possess with individuals on campus and off-campus. Our work moves the field from an approach that too often aims to "fix" the perceived internal deficits first-generation college students possess to an approach that focuses on the assets they possess and can leverage to be successful. Our findings add to the literature that documents and illustrates the staunch support FGC students enjoy from their families; it also demonstrates specific ways in which FGC students successfully leverage existing social connections to form an engineering pathway. By comparing FGC and CGC students, we illustrate the many ways in which FGC students are similar to their CGC counterparts and a few ways in which they are different. These similarities and differences bring attention to ways the educational system can be altered to promote the success of all students by leveraging the strengths of their existing social networks and by providing additional unambiguous paths to forming new network connections. While each of the stakeholders mentioned in the implications section can function in specific ways to increase engineering students' social capital, we recognize that collaborative efforts have the most potential to support enrollment and persistence in engineering. All units and all individuals across campus are potential sources of support. Concerted actions can work to shape inclusive recruitment and inclusive retention practices within engineering education ecosystems.

We anticipate that a future study that includes students who did not choose engineering as a college major could uncover significant differences in the social networks of these students compared to the participants in our work. We anticipate that such a study would also continue to uncover the unique strengths FGC students demonstrate in their educational pathways. Other theoretical frameworks such as Yosso's (2005) Community Cultural Wealth, which includes social capital and other forms of capital, will be needed in future research to fully describe the nuanced assets that FGC students bring to bear on their educational journey. Additionally, longitudinal studies are needed to provide a more nuanced understanding of social capital development over time. While conducting such a study with federal funding is difficult given many agencies' grant cycles, we assert the need for such future work. Finally, we anticipate that our findings can be expanded to other disciplines in STEM.

\section{Implications}

Our work has implications for a variety of stakeholders, including engineering professors, university personnel, university administrators, professors of education, STEM program personnel, members of professional organizations, and engineers in the workforce. Ultimately, we found that all participants in our study described multiple alters encouraging and supporting them. The 
opportunities for these stakeholders to function as social capital alters are diverse and all offer educational benefits. Everyone has a role to play.

\section{University professors in engineering}

It does not come as a surprise to anyone that faculty members have a profound influence on students' persistence when they experience difficulties and when they need access to resources. Faculty may play the most central role in challenging the pervasive, deficit-based stereotypes first-generation college students face. Faculty who reinforce the view that all students bring unique talents and perspectives to engineering classrooms not only positively impact first-generation college students, they also positively influence access to resources for all students. Additionally, they make internal structures and norms less ambiguous to students. Our data indicate that many students first learned of campus resources through their professors. Professors can maximize their influence by maintaining an open-door policy, so students feel comfortable asking questions and seeking career advice. Encouraging students to attend office hours, utilize tutoring centers, form peer study groups, and join student chapters of professional organizations helps students to access and activate the available resources on campus. Faculty can also be proactive in sharing undergraduate research opportunities to all students. This type of faculty support not only promotes opportunities to deepen relationships with the faculty member but also provides access to graduate students, which can serve as near-peer social capital alters. Informal demonstration and discussion of post-secondary training beyond the undergraduate years from doctoral students-and by extension exposure to career pathways into academiapresent a valuable opportunity for undergraduates to develop plans for future studies.

Off-campus, professors can also introduce students to their professional engineering colleagues. These introductions enable students to build and expand their professional networks. Engineering faculty can share their professional experiences (particularly those in industry settings) with their students and disseminate opportunities for students to participate in professional development, undergraduate research, internships, or co-operative education with contacts inside their own professional networks. Our data suggest that faculty who provide practical applications and examples of engineering principles in their courses promote student persistence by helping students develop a clearer idea of future career pathways.

\section{Academic advisors and other institutional agents}

In addition to faculty, many other individuals on campuses provide important and consistent expressive and instrumental social capital to students. Participants in our study discussed being able to access resources because university personnel such as academic advisors, undergraduate coordinators, tutoring center personnel, peer mentoring program directors, and career center personnel were proactive in disseminating resources through email and in-person conversations. Participants in this study spoke of trusting relationships with university personnel who discussed students' academic and career goals, helped them understand their own strengths and weaknesses, and offered moral support when students faced setbacks. Because of these trusting relationships, students took the individuals' advice, accessing and activating numerous resources as needed. While the personnel structure of each campus varies, we recommend that university personnel connect with students as early and as often as possible (e.g., during student orientation or early in each term). Most importantly, while our data indicate that all students benefit from strong peer mentoring programs, university personnel should support such programs, especially because FGC students benefit even more than their counterparts. FGC students reported that when they felt overwhelmed, they initially assumed that their only viable option when struggling was dropping out. Formal and informal peer mentoring programs convinced them to persist even when overwhelmed.

\section{University administrators}

Administrators set a tone of collaboration between engineering department faculty and staff which can encourage (or discourage) student involvement and persistence. Administrative staff plays an active role in the success of FGC engineering students by supporting the budget lines of and advocating for recruitment and outreach programs. University administrators can also enhance student involvement by providing physical spaces (e.g., study areas, maker spaces, design spaces, and project labs) and by protecting and funding blended academic and social spaces (e.g., structured study groups, peer mentoring programs, co-curricular activities) where students interact with each other and support each other, fostering the crucial expressive and instrumental social capital described by our participants.

\section{Professors of education}

Our work demonstrates that teachers at all levels play key roles in developing future engineers. While their influence may start as early as kindergarten, our work highlights middle and high school teachers as important alters for future engineering students. Middle school teachers and high school teachers frequently identify students with talent and skills related to engineering. Middle school teachers and high school teachers suggest STEM summer camps or after-school programs, 
encourage students to consider engineering as a college major, and point students to information about engineering. Unfortunately, even though middle school teachers and high school teachers possess the opportunities to provide information and resources, the literature demonstrates that their efficacy regarding engineering is sometimes low. In the absence of possessing engineering training themselves, teachers may hesitate to talk about engineering because they feel unfamiliar with the subject (Brophy, Klein, Portsmore, \& Rogers, 2008; Skaalvik \& Skaalvik, 2007; Trenor, Yu, Grant, \& Salem, 2009). K-12 teachers can express openness to work with engineers and engineering education university faculty and researchers to increase awareness of the engineering profession. Experts can provide teachers and preservice teachers with the resources they need to understand and to talk with students about what engineers do, identify necessary pre-college coursework, and guide students towards engineering-related resources.

\section{STEM programs and program personnel}

STEM programs serve to educate and prepare future engineering college students, so their expansion is in the interest of the engineering field. Our interview data demonstrate that students benefit from STEM programs and STEM events; as a result, students reported that these program personnel provided clear academic pathways, and their entry into engineering majors was smoother. Summer programs where students learned about different majors, attended workshops, took short classes, and visited lectures, organized in part by local colleges, introduced students to engineering. Continued-and expanded-federal and industry funding is needed for STEM programs, including financial support for students from low socioeconomic backgrounds.

Additionally, our interview data demonstrate that STEM program personnel who reach out to parents and teachers also increase awareness of engineering careers and pre-college programs. Teachers need to know about the existence and value of STEM-related opportunities. STEM program personnel can equip teachers to help parents recognize and value the potential benefits participation in STEM programs may hold for their child's future. Many families identify engineering as a desirable career path, so an early exposure to engineering may assist family members in encouraging their children to pursue unfamiliar educational territory in engineering degrees. As emphasized above, families play an essential role in students' decisions to enter into engineering and to persist through struggles. The encouragement to pursue careers within engineering from non-engineering parents and family members underscores the important influence and role families may play in recruitment efforts. Furthermore, such STEM programs need to be fiscally possible for all interested students.

\section{Members of professional organizations}

Our findings indicate that providing opportunities for undergraduates to learn about the daily experiences of working engineers are particularly salient. We recommend that student chapters of professional societies seek to involve engineering students as early as possible. By maintaining a presence at campus events as early as orientation, student and alumni members of organizations can encourage students to join on-campus chapters and professional networks. Organizations that provide professional development opportunities for students (e.g., résumé writing skills and interviewing techniques), as well as opportunities to interact with engineering professionals from a variety of disciplines, benefit students with instrumental and expressive social capital. This instrumental and expressive social capital supports the daily decision to remain committed to an engineering program.

\section{Engineers}

Engineers in the workforce can support FGC engineering students in many ways. They can volunteer their time with $\mathrm{K}-12$ students and their teachers, college students, university personnel, and professors. Engineering companies can encourage their employees to participate in company-sponsored outreach, volunteer in student chapters of professional organizations, and create shadowing or internship positions that allow engineers to share experiences and educational paths with students.

\section{Abbreviations}

STEM: Science, technology, engineering, and mathematics; FGC: Firstgeneration college; CGC: Continuing-generation college

\section{Acknowledgements \\ N/A}

\begin{abstract}
Authors' contributions
This work was funded by JPM's National Science Foundation Faculty Early Career Development (CAREER) award. As the principal investigator, JPM led the research team and participated in all aspects of the research and writing, including the conception and design of the project, data collection, analysis, and research oversight. SKS, KWC, and ALP provided analytic support. SKS made significant contributions to the writing of the paper, performed additional data analyses, and provided critical revisions of the manuscript. The author(s) read and approved the final manuscript.
\end{abstract}

\section{Authors' information}

Julie P. Martin is an associate professor of Engineering Education at The Ohio State University.

Shannon K. Stefl is a Teaching Consultant and Professional Developer at the Office of Teaching Effectiveness and Innovation at Clemson University.

Lindsey W. Cain is an assistant professor of Chemistry at Anderson University. Aubrie L. Pfirman and is an assistant professor of Physical Sciences at Lander University. 


\section{Funding}

Funding for this work was provided by the National Science Foundation (NSF) grant number EEC-0950710 Any opinions, findings, and conclusions or recommendations expressed in this material are those of the authors and do not necessarily reflect the views of the NSF.

\section{Availability of data and materials}

N/A

\section{Competing interests}

The authors declare that they have no competing interests.

\section{Author details}

${ }^{1}$ Department of Engineering Education, The Ohio State University, 244 Hitchcock Hall, 2020 Neil Avenue, Columbus, OH 43210, USA. ${ }^{2}$ Office of Teaching Effectiveness and Innovation, Clemson University, 201 Watt Family Innovation Center, Clemson, SC 29634, USA. ${ }^{3}$ Department of Biology and Chemistry, Anderson University, 316 Boulevard, Anderson, SC 29621, USA. ${ }^{4}$ Department of Physical Sciences, Lander University, 320 Stanley Ave., Greenwood, SC 29649, USA.

Received: 21 October 2019 Accepted: 2 July 2020

Published online: 03 August 2020

\section{References}

Borrego, M., Douglas, E. P., \& Amelink, C. T. (2009). Quantitative, qualitative, and mixed research methods in engineering education. Journal of Engineering Education, 98(1), 53. https://doi.org/10.1002/j.2168-9830.2009.tb01005.x.

Brophy, S., Klein, S., Portsmore, M., \& Rogers, C. (2008). Advancing engineering education in P-12 classrooms. Journal of Engineering Education, 97(3), 369. https://doi.org/10.1002/j.2168-9830.2008.tb00985.x.

Castro, E. L. (2014). "Underprepared" and "at-risk": Disrupting deficit discourses in undergraduate STEM recruitment and retention programming. Journal of Student Affairs Research and Practice, 51(4), 407-419. https://doi.org/10.1515/ jsarp-2014-0041.

Cataldi, E. F., Bennett, C. T., \& Chen, X. (2018). First-generation students: College access, persistence, and postbachelor's outcomes. Stats in Brief. NCES. 2018421. National Center for Education Statistics.

Chen, X., \& Carroll, C. D. (2005). First generation students in postsecondary education: A look at their college transcripts, Postsecondary Education Descriptive Analysis Report No. NCES 2005-171 (). Washington, DC: National Center for Education Statistics.

Chism, N. V. N., Douglas, E., \& Hilson Jr., W. J. (2008). Qualitative research basics: A guide for engineering educators, Rigorous Research in Engineering Education Report No. NSF DUE-0341127 (). Arlington: National Science Foundation.

Choy, S. (2001). Students whose parents did not go to college: Postsecondary access, persistence, and attainment [Brochure No. NCES 2001126]. In B. Kridl, \& A. Livingston (Eds.), Findings from the condition of education. Washington, DC: National Center for Education Statistics.

Corbin, J., \& Strauss, A. (2008). Basics of qualitative research: Techniques and procedures for developing grounded theory. Thousand Oaks: Sage.

Creswell, J. W. (2013). Qualitative inquiry and research design: Choosing among five approaches, (3rd ed., ). Los Angeles: Sage.

Crotty, M. (1998). The foundations of social research: Meaning and perspective in the research process. Los Angeles: Sage.

Dika, S. L. (2003). The effects of self-processes and social capital on the educational outcomes of high school students. Blacksburg: Virginia Polytechnic Institute and State University.

Dika, S. L., \& Singh, K. (2002). Applications of social capital in educational literature: A critical synthesis. Review of Educational Research, 72(1), 31-60. https://doi.org/10.3102/00346543072001031.

Garrison, N. J., \& Gardner, D. S. (2012). Assets first generation college students bring to the higher education setting. In Paper presented at the Association for the Study of Higher Education Annual Conference, Las Vegas, NV https:// files.eric.ed.gov/fulltext/ED539775.pdf.

Gofen, A. (2009). Family capital: How first-generation higher education students break the intergenerational cycle. Family Relations, 58(1), 104-120. https://doi. org/10.1111/j.1741-3729.2008.00538.x.

Granovetter, M. S. (1973). The strength of weak ties. American Journal of Sociology, 78(6), 1360-1380. https://doi.org/10.1086/225469.
Harper, S. R. (2010). An anti-deficit achievement framework for research on students of color in STEM. Special Issue: Students of Color in STEM, 148, 63-74. https://doi.org/10.1002/ir.362.

Holland, N. E. (2010). Postsecondary education preparation of traditionally underrepresented college students: A social capital perspective. Journal of Diversity in Higher Education, 3(2), 111. https://doi.org/10.1037/a0019249.

Johnson, A., Brown, J., Carlone, H., \& Cuevas, A. K. (2011). Authoring identity amidst the treacherous terrain of science: A multiracial feminist examination of the journeys of three women of color in science. Journal of Research in Science Teaching, 48(4), 339-366. https://doi.org/10.1002/tea.20411.

Leech, N. L., \& Onwuegbuzie, A. J. (2007). An array of qualitative data analysis tools: A call for data analysis triangulation. School Psychology Quarterly, 22(4), 557. https://doi.org/10.1037/1045-3830.22.4.557.

Lin, N. (1999). Building a network theory of social capital. Connections, 22(1), 28-51.

Lin, N. (2001). Social capital: A theory of social structure and action (Structural Analysis in the Social Sciences). New York: Cambridge University Press.

Lin, N., \& Dumin, M. (1986). Access to occupations through social ties. Social Networks, 8(4), 365-385. https://doi.org/10.1016/0378-8733(86)90003-1.

Lohfink, M. M., \& Paulsen, M. B. (2005). Comparing the determinants of persistence for first generation and continuing-generation students. Journal of College Student Development, 46(4), 409-428. https://doi.org/10.1353/csd. 2005.0040 .

Mannon, S. E., \& Schreuders, P. D. (2007). All in the (engineering) family? - The family occupational background of men and women engineering students. Journal of Women and Minorities in Science and Engineering, 13(4). https://doi. org/10.1615/JWomenMinorScienEng.v13.i4.20.

Martin, J. P., \& Garza, C. (2020). Centering the marginalized student's voice through autoethnography: IMPLICATIONS for engineering education research. Studies in Engineering Education, 1(1), 1-20. https://doi.org/10.21061/see.1.

Martin, J. P., Miller, M. K. \& Simmons, D. R. (2014). Exploring the theoretical social capital "deficit" of first generation college students: Implications for engineering education. International Journal of Engineering Education, 30(4), 822-836.

Martin, J. P., Simmons, D. R., \& Yu, S. L. (2013). The role of social capital in the experiences of Hispanic women engineering majors. Journal of Engineering Education, 102(2), 227-243. https://doi.org/10.1002/jee.20010.

Martin, J. P., Simmons, D. R., \& Yu, S. L. (2014). Family roles in engineering undergraduates' academic and career choices: Does parental educational attainment matter? International Journal of Engineering Education, 30(1), 136-149.

McCallister, L., \& Fischer, C. S. (1978). A procedure for surveying personal networks. Sociological Methods \& Research, 7(2), 131-148. https://doi.org/10. 1177/004912417800700202

Moll, L. C., Amanti, C., Neff, D., \& Gonzalez, N. (1992). Funds of knowledge for teaching: Using a qualitative approach to connect homes and classrooms. Theory Into Practice, 31(2), 132-141. https://doi.org/10.1080/ 00405849209543534

Morse, J. M., Barrett, M., Mayan, M., Olson, K., \& Spiers, J. (2002). Verification strategies for establishing reliability and validity in qualitative research. International Journal of Qualitative Methods, 1(2), 13-22. https://doi.org/10. $1177 / 160940690200100202$.

Moschetti, R. V., \& Hudley, C. (2015). Social capital and academic motivation among first generation community college students. Community College Journal of Research and Practice, 39(3), 235-251. https://doi.org/10.1080/ 10668926.2013 .819304$.

Orbe, M. P. (2004). Negotiating multiple identities within multiple frames: An analysis of first-generation college students. Communication Education, 53(2), 131-149. https://doi.org/10.1080/03634520410001682401.

Pascarella, E. T., Pierson, C. T., Wolniak, G. C., \& Terenzini, P. T. (2004). First generation college students: Additional evidence on college experiences and outcomes. Journal of Higher Education, 75(3), 249-284. https://doi.org/10. 1353/jhe.2004.0016

Pawley, A. L. (2019). Learning from small numbers: Studying ruling relations that gender and race the structure of US engineering education. Journal of Engineering Education, 108(1), 13-31. https://doi.org/10.1002/jee.20247.

Portes, A. (1998). Social capital: Its origins and applications in modern sociology. Review of Sociology, 24(1), 1-24. https://doi.org/10.1146/annurev.soc.24.1.1.

Rahm, J., \& Moore, J. C. (2016). A case study of long-term engagement and identity-in-practice: Insights into the STEM pathways of four underrepresented youths. Journal of Research in Science Teaching, 53(5), 768801. https://doi.org/10.1002/tea.21268.

Ryan, G. W., \& Bernard, H. R. (2003). Techniques to identify themes. Field Methods, 15(1), 85-109. 
Skaalvik, E. M., \& Skaalvik, S. (2007). Dimensions of teacher self-efficacy and relations with strain factors, perceived collective teacher efficacy, and teacher burnout. Journal of Educational Psychology, 99(3), 611. https://doi.org/10.1037/ 0022-0663.99.3.611.

Son, J., \& Lin, N. (2012). Network diversity, contact diversity, and status attainment. Social Networks, 34(4), 601-613. https://doi.org/10.1016/j.socnet. 2012.06.006.

Syed, M., Azmitia, M., \& Cooper, C. R. (2011). Identity and academic success among underrepresented ethnic minorities: An interdisciplinary review and integration. Journal of Social Issues, 67(3), 442-468. https://doi.org/10.1111/j. 1540-4560.2011.01709.x

Trenor, J., Yu, S., Grant, D., \& Salem, H. (2009). Participation in a research experience for teachers program: Impact on perceptions and efficacy to teach engineering. In Paper presented at the Annual Conference of the American Society for Engineering Education, Austin, TX.

Trenor, J. M. (2009). A phenomenological inquiry of the major choice processes of an overlooked demographic: First generation college students in engineering. In Proceedings of the 2009 Research in Engineering Education Symposium Research in Engineering Education Network.

Valencia, R. R. (1997). Conceptualizing the notion of deficit thinking. In The evolution of deficit thinking: Educational thought and practice, Stanford Education and Policy Book Series No. 19 (pp. 1-12). New York: Routledge.

van der Gaag, M. P. J. (2005). Measurement of individual social capital. The Netherlands: Doctoral dissertation, University of Groningen Retrieved from https://www.researchgate.net/profile/Martin_Van_Der_Gaag/publication/304 74825_Measurement_of_individual_social_capital/links/53d782ec0cf29265323 cca5c/Measurement-of-individual-social-capital.pdf.

van der Gaag, M. P. J., \& Snijders, T. A. B. (2003). A comparison of measures for individual social capital. In Paper presented at the Creation and returns of Social Capital conference, Amsterdam, The Netherlands.

Walther, J., Pawley, A. L., \& Sochacka, N. W. (2015). Exploring ethical validation as a key consideration in interpretive research quality. In Proceedings of the ASEE Annual Conference. Seattle. https://doi.org/10.18260/p.24063.

Walther, J., Sochacka, N. W., \& Kellam, N. N. (2013). Quality in interpretive engineering education research: Reflections on an example study. Journal of Engineering Education, 102(4), 626-659. https://doi.org/10.1002/jee.20029.

Yosso, T. J. (2005). Whose culture has capital? A critical race theory discussion of community cultural wealth. Race Ethnicity and Education, 8(1), 69-91. https:// doi.org/10.1080/1361332052000341006.

\section{Publisher's Note}

Springer Nature remains neutral with regard to jurisdictional claims in published maps and institutional affiliations.

\section{Submit your manuscript to a SpringerOpen ${ }^{\circ}$ journal and benefit from:}

- Convenient online submission

- Rigorous peer review

- Open access: articles freely available online

High visibility within the field

- Retaining the copyright to your article

Submit your next manuscript at $\boldsymbol{\nabla}$ springeropen.com 